\title{
ANALISA PENDAPATAN JASA ANGKUT BARANG DAN BEBAN USAHA TERHADAP LABA USAHA PADA BMT DARUSSALAM PERIODE 2019.
}

\author{
Rizal Zaelani* \\ Program Studi Akuntansi, \\ Sekolah Tinggi Ilmu Ekonomi PGRI Sukabumi \\ rizal@stiepgri.ac.id \\ Wawan Ruswandi ** \\ Program Studi Manajemen, \\ Sekolah Tinggi Ilmu Ekonomi PGRI Sukabumi \\ wawanruswandi@stiepgri.ac.id
}

\begin{abstract}
ABSTRAK
Penelitian dilakukan karena ada masalah mengenai analisa pendapatan jasa dan beban usaha terhadap laba usaha pada BMT DARUSSALAM selama periode 2019 yaitu sangat stabil.

Teknik analisis data yang digunakan dalam penelitian ini adalah dengan menggunakan metode expost facto merupakan penelitian yang bertujuan menemukan penyebab yang memungkinkan perubahan perilaku, gejala atau fenomena yang di sebabkan oleh suatu peristiwa, perilaku atau hal-hal yang menyebabkan perubahan pada variabel bebas yang secara keseluruhan sudah terjadi.

Hasil dari penelitian menunjukkan pendapatan jasa, beban usaha dan laba usaha cenderung stabil pada periode 2019 tidak ada kenaikan yang signifikan atau penurunan yang signifikan.
\end{abstract}

Kata Kunci : Pendapatan Jasa, Beban Usaha, dan Laba Usaha.

\begin{abstract}
The study was conducted because there was a problem regarding the analysis of freight services and operating expenses for operating profit at BMT DARUSSALAM during tehe 2019 period was stable.

The data analysis technique used in this research is to use the ex post facto method which is a research that aims to find causes that allow changes in behavior, symptoms or phenomena caused by an event, behavior or things that cause changes in the independent variables as a whole.

The results of the study show that service income, operating expenses and operating profit tended to be stable in the 2019 period there was no significant increase or significant decrease.
\end{abstract}

Keywords : Service Revenue, Operating Expenses, and Operating Profit.

\section{PENDAHULUAN}

Pendapatan merupakan unsur yang harus dilakukan dalam melakukan suatu usaha karena bisa jadi pendapatan adalah salah satu tolok ukur keberhasilan. Pendapatan (revenue) adalah arus masuk bruto dari manfaat ekonomis selama periode berjalan yang muncul dalam rangkaian kegiatan biasa dari sebuah entitas ketika arus masuk dihasilkan dalam penambahan modal, selain yang berkaitan dengan kontribusi pemegang ekuitas. Pendapatan adalah hasil akhir dari perhitungan pendapatan dan laba dikurangi biaya dan kerugian pada periode itu. 
Beban dalam arti luas termasuk semua biaya yang sudah habis masa berlakunya yang dapat dikurangkan dari pendapatan, beban itu sendiri terjadi karena dua sebab, pertama yang berasal dari cost yang sudah

expired (melampaui masanya) dan yang kedua karena penggunaan maksudnya beban itu hadir kalau kita sudah melakukan pemakaian tertentu atau utilitas. Beban (expenses) adalah expired cost yaitu pengorbanan yang diperlukan atau dikeluarkan untuk merealisasi hasil, beban ini dikaitkan dengan revenue pada periode yang berjalan.

BMT DARUSSALAM adalah salah satu perusahaan yang bergerak di bidang jasa transportasi, BMT DARUSSALAM melakukan kegiatan usaha atau bisnisnya adalah memberikan pelayanan jasa transportasi memberikan pelayanan jasanya untuk konsumen, yang membutuhkan pengiriman barang, Pindahan Rumah, Keramik, Bahan Makanan, dan lain sebagainya dengan tujuan membantu kelancaran usaha para pelaku usaha baik perusahan maupun perseorangan secara efektif dan efisien, BMT DARUSSALAM dalam suatu konsep pelayanan sehingga memberikan kemudahan sebagai perusahaan penyedia layanan jasa transportasi yang terpercaya di dukung dengan integritas dan dedikasi terhadap kepuasan pelanggan, BMT DARUSSALAM telah menjadi pilihan utama sebagai partner transportasi, cakupan wilayahnya untuk saat ini baru meliputi Sumatra, Jawa Barat, Jawa tengah, Jakarta, dan Jawa Timur. Dalam laporan keuangan perusahaan BMT DARUSSALAM ada sisi laba rugi dan neraca, dalam hal ini akan dibahas di sisi laba rugi tentang pendapatan jasa dan biaya usaha atau yang lebih sering di sebut dengan uang jalan dan di perusahaan terhadap laba usaha atau laba kotor dalam hal ini.

\section{KAJIAN PUSTAKA}

\section{Laba Usaha}

"Laba merupakan pendapatan yang diperoleh apabila jumlah finansial (uang) dari aset neto pada akhir periode (di luar dari distribusi dan kontribusi pemilik perusahaan) melebihi aset neto pada awal periode"[1].

Pengertian laba juga dapat dilihat dari dua sisi ilmu yaitu secara ekonomi murni atau secara akuntansi. Secara ilmu ekonomi, laba diartikan sebagai keuntungan yang didapat investor dalam suatu kegiatan bisnis yang sudah dikurangi dengan biaya operasional. Sedangkan dalam akuntansi, laba didefinisikan sebagai selisih antara harga penjualan dengan biaya yang dikeluarkan saat produksi, ada beberapa jenis laba, yaitu : Laba Kotor, Laba Operasi, Laba Sebelum Pajak, dan Laba Bersih. Laba kotor tentunya memiliki manfaat dalam pelaksanaan suatu usaha [1]. Dari laba kotor, para pelaku usaha dapat menilai apakah usaha yang dijalankannya sudah efisien dalam hal pemanfaatan tenaga kerja. Jika laba kotor menunjukkan kondisi defisit, hal ini berarti tenaga kerja tidak melakukan tanggung jawabnya secara efisien. Dengan demikian, laba kotor dapat digunakan 
sebagai dasar untuk evaluasi kinerja tenaga kerja. Laba kotor adalah ukuran seberapa efisien suatu perusahaan menggunakan tenaga kerja dan pasokan untuk memproduksi barang atau menawarkan jasa kepada customer.

Laba kotor merupakan gambaran umum mengenai keuntungan yang diperoleh sebuah usaha, laba kotor belum bisa digunakan/dialokasikan sepenuhnya karena masih harus diproses untuk mendapatkan laba bersih. Biasanya, perusahaan menggunakan istilah pendapatan kotor dan laba kotor secara bergantian. Ini berarti bahwa menurut bisnis, laba kotor adalah jumlah penjualan bersih setelah dikurangi harga pokok penjualan. Dengan kata lain, jumlah laba atau pendapatan yang tersisa setelah semua biaya yang telah dipertanggungjawabkan. Jenis biaya seperti biaya penjualan, administrasi, atau pajak tidak tidak termasuk dalam perhitungan laba kotor bisnis menggunakan laba kotor untuk menghitung jumlah sisa pendapatan yang dapat digunakan untuk membayar biaya-biaya tersebut.

\section{Pendapatan Jasa}

Pendapatan jasa dalam perusahaan jasa sangat berpengaruh pada kelangsungan suatu usaha, semakin besar pendapatan yang diperoleh, maka semakin besar kemampuan usaha untuk membiayai segala pengeluaran atau beban operasional harian yang akan dilakukan. Pendapatan merupakan unsur yang harus dilakukan dalam melakukan suatu usaha karena bisa jadi pendapatan adalah salah satu tolok ukur keberhasilan. Pendapatan adalah arus masuk bruto dari manfaat ekonomi yang timbul dari aktivitas normal perusahaan selama suatu periode jika aliran masuk tersebut menghasilkan peningkatan ekuitas yang tidak berasal dari kontribusi investasi. Pendapatan adalah hasil akhir dari perhitungan pendapatan dan laba dikurangi biaya dan kerugian pada periode itu. Pendapatan salah satu unsur-unsur dari Laba, selain Beban, Biaya, Untung-Rugi, Penghasilan.

"Penghasilan (income) adalah kenaikan manfaat ekonomi selama periode pelaporan dalam bentuk arus masuk atau peningkatan aset, atau penurunan kewajiban yang mengakibatkan kenaikan ekuitas yang tidak berasal dari kontribusi penanam modal. Penghasilan meliputi pendapatan (revenue) dan keuntungan (gain). Pendapatan adalah penghasilan yang timbul dalam pelaksanaan aktivitas entitas yang biasa dan dikenal dengan sebutan yang berbeda seperti penjualan, imbalan, bunga, dividen, royalti dan sewa"[2].

Dalam hal ini pendapatan jasa angkut barang merupakan pendapatan yang dihasilkan dari perusahaan yang memberikan jasa, yaitu kegiatan transportasi dalam memindahkan barang dan penumpang dari satu tempat ke tempat lain atau dapat dikatakan sebagai kegiatan ekspedisi. Sebagai suatu kegiatan jasa dalam memindahkan barang atau pun penumpang dari suatu tempat ke tempat lain, pengangkutan berperan sekali dalam mewujudkan terciptanya pola distribusi nasional yang begitu dinamis. 


\section{Beban Usaha}

Beban merupakan suatu penurunan nilai ekonomi yang berupa kas keluar atau aktiva berkurang, biasanya beban dianggap sebagai kewajiban yang dapat menyebabkan nilai ekuitas menurun, umumnya beban dianggap sebagai pengorbanan atau kewajiban yang sebelumnya telah terjadi.

"Beban (expenses) adalah penurunan manfaat ekonomi selama satu periode akuntansi dalam bentuk arus keluar atau berkurangnya asset atau terjadinya liabilitas yang mengakibatkan penurunan ekuitas yang tidak menyangkut pembagian kepada penanam modal. Definisi beban mencakup baik beban yang timbul dalam pelaksanaan aktivitas perusahaan yang biasa maupun kerugian (loss)" [3].

Beban adalah suatu yang dikeluarkan atau di korbankan dengan tujuan untuk dapat memperoleh pendapatan, misalnya akun-akun yang terdapat dalam laporan laba rugi seperti beban listrik, beban penyusutan, beban sewa, beban gaji, dan lain-lain. Beban atau expenses adalah pengurangan atas pendapatan yang akan menghasilkan laba bersih sebelum adanya pajak dalam laporan laba-rugi. Maka dalam hal ini beban diperkirakan berupa jenis yang paling banyak jumlahnya, dapat diklarifikasi secara sederhana menjadi beban operasional, beban perolehan pendapatan, dan lain-lain. Beban (expenses) adalah penurunan manfaat ekonomi selama satu periode akuntasi dalam bentuk arus kas keluar atau berkurangnya aktiva atau terjadinya kewajiban mengakibatkan penurunan ekuitas yang tidak menyangkut pembagian kepada penanaman modal.

\section{METODOLOGI PENELITIAN}

Metode penelitian adalah pembahasan mengenai konsep teoritik tentang berbagai metode, kelebihan dan kelemahannya yang dalam karya ilmiah kemudian dilanjtkan dengan pemilihan metode yang digunakan. Metodologi adalah pengkajian terhadap langkah-langkah dalam menggunakan metode. Sedengkan metode penelitian adalah ilmu yang mengemukakan secara teknis tentang metode yang digunakan dalam penelitian menurut [3].

Metode expost facto merupakan penelitian yang bertujuan menemukan penyebab yang memungkinkan perubahan perilaku, gejala atau fenomena yang di sebabkan oleh suatu peristiwa, perilaku atau hal-hal yang menyebabkan perubahan pada variabel bebas yang secara keseluruhan sudah terjadi. Expost facto berarti "sesudah fakta" karena sebab yang akan diteliti telah mempengaruhi variabel lain. Sedangkan secara umum, expost facto merupakan penelitian yang dilakukan setelah apa yang akan diteliti itu terjadi. Penelitian yang dilakukan untuk meneliti peristiwa yang telah terjadi yang kemudian meruntut ke belakang untuk mengetahui faktor-faktor yang dapat menimbulkan kejadian tersebut. Penelitian expost facto bertujuan untuk melacak 
kembali, jika dimungkinkan, apa yang menjadi faktor penyebab terjadinya sesuatu. Penelitian expost facto menggunakan variabel bebas atribut yaitu peneliti tidak dapat menentukan responden secara bebas artinya responden tersebut telah ada sebelum penelitian tersebut. Pada judul tersirat faktor -faktor yang mempengaruhi suatu hal yang akan diteliti yang berasal dari sebab permasalahan yang sekarang terjadi. Dengan kata lain, penelitian ini untuk menentukan apakah perbedaan yang terjadi antar kelompok subjek dalam variabel independen menyebabkan terjadinya perbedaan pada variabel dependen.

\section{Operasionalisasi Variabel Penelitian}

\begin{tabular}{|c|c|c|c|}
\hline Variable & Definisi & Pengukuran & Skala \\
\hline $\begin{array}{l}\text { Pendapatan Jasa } \\
\text { Angkut Barang }\end{array}$ & $\begin{array}{l}\text { Pengertian pendapatan menurut [2] } \\
\text { adalah: } \\
\text { Penghasilan (income) adalah kenaikan } \\
\text { manfaat ekonomi selama satu } \\
\text { periode akuntansi dalam bentuk } \\
\text { pemasukan atau penambahan aset } \\
\text { atau penurunan kewajiban yang } \\
\text { mengakibatkan kenaikan ekuitas yang } \\
\text { tidak berasal dari kontribusi penanam } \\
\text { modal. }\end{array}$ & $\begin{array}{l}\text { Pendapatan }=\text { Tonase } \mathrm{x} \\
\text { Harga Tarif }\end{array}$ & Ordinal \\
\hline Beban Usaha & $\begin{array}{l}\text { [3], beban (expeses) adalah "Biaya yang } \\
\text { dikorbankan atau dikonsumsi dalam } \\
\text { rangka memperoleh pendapatan } \\
\text { (revenues) dalam suatu periode akuntansi } \\
\text { tertentu." }\end{array}$ & $\begin{array}{l}\text { Beban Usaha = Tonase } \\
\text { x Harga Tarif x 55\% }\end{array}$ & Ordinal \\
\hline $\begin{array}{l}\text { Laba Usaha (Laba } \\
\text { Kotor) }\end{array}$ & $\begin{array}{l}\text { [1] mendefinisikan laba sebagai berikut: } \\
\text { "Laba adalah kenaikan manfaat ekonomi } \\
\text { selama suatu periode akuntansi (misalnya, } \\
\text { kenaikan aset atau penurunan kewajiban) } \\
\text { yang menghasilkan peningkatan ekuitas, } \\
\text { selain yang menyangkut transaksi dengan } \\
\text { pemegang saham." }\end{array}$ & $\begin{array}{l}\text { Laba Usaha (Laba } \\
\text { Kotor) = Pendapatan } \\
\text { Jasa + Beban Usaha } \\
\text { Daerah menentukan } \\
\text { besar atau kecil yang } \\
\text { di hasilkan. } \\
\text { Muatan pun } \\
\text { menentukan besar } \\
\text { kecil yang di dapatkan }\end{array}$ & Ordinal \\
\hline
\end{tabular}

\section{Metode Analisis Data}

[4]"Penelitian komparatif adalah penelitian yang membandingkan dua gejala atau lebih. Penelitian komparatif dapat berupa komparatif deskriptif (descriptive comparative) maupun komparatif korelasional (correlation comparative)" . Komparatif deskriptif membandingkan variabel yang sama untuk sampel yang berbeda.

"Analisis komparasi atau perbandingan adalah prosedur statistik guna menguji perbedaan diantara dua kelompok data (variabel) atau lebih. Uji ini bergantung pada jenis data (nominal, ordinal, interval/rasio) dan kelompok sampel yang diuji” [4]. 
Komparasi antara dua sampel yang saling lepas (independen) yaitu sampel-sampel tersebut satu sama lain terpisah secara tegas dimana anggota sampel yang satu tidak menjadi anggota sampel lainnya. Analisis perbandingan digunakan untuk membandingkan rata-rata anatara dua atau lebih kelompok sampel data. Analisis perbandingan adalah teknik analisis laporan keuangan yang dilakukan dengan cara menyajikan laporan keuangan secara horizontal dan membandingkan antara satu dengan yang lain, dengan menunjukkan informasi keuangan atau data lain baik dalam rupiah atau dalam unit.

[4] "Ada dua metode analisis yang digunakan oleh setiap penganalisi laporan keuangan, yaitu analisis horisontal dan analisis vertikal. Analisis horisontal adalah analisis dengan mengadakan perbandingan laporan keuangan untuk beberapa periode atau beberapa saat sehingga akan diketahui perkembangannya. Analisis vertikal adalah apabila laporan keuangan yang dianalisis hanya melupiti satu periode atau satu saat saja, yaitu dengan memperbandingkan antara akun yang satu dengan akun yang lain dalam laporan keuangan tersebut sehingga hanya kan diketahui keadaan keuangan atau hasil operasi pada saat itu saja”.

Teknik perbandingan juga dapat menunjukkan kenaikan dan penurunan dalam rupiah atau unit dan juga dalam persentase atau perbandingan dalam bentuk angka perbandingan atau rasio. Tujuan analisis perbandingan ini adalah untuk mengetahui perubahan-perubahan berupa kenaikan atau penurunan pos-pos laporan keuangan atau data lainnya dalam dua atau lebih periode yang dibandingkan. Perbandingan dapat juga dilakukan antara laporan yang sudah dikonversikan ke angka indeks atau laporan bentuk common size awam. Metode ini dianggap lebih mudah dan lebih sederhana menafsirkannya dibanding laporan aslinya. Dalam melakukan analisis laporan keuangan teknik perbandingan ini kita dapat membandingkannya dengan angka-angka laporan keuangan tahun lalu, angka laporan keuangan perusahaan sejenis, rasio rata-rata industri, dan rasio normatif sebagai perbandingan.

\section{HASIL PENELITIAN DAN \\ PEMBAHASAN}

Berdasarkan data dari perusahaan kemudian peneliti melakukan rekapitulasi pendapatan jasa transportasi, dan peneliti menganalisis kenaikan atau penurunan pendapatan jasa transportasi pada setiap bulannya, maka hasilnya disajikan sebagai berikut : 


\section{Analisis kenaikan atau penurunan pendapatan jasa Transportasi BMT DARUSSALAM} periode 2019 (Dalam Ribuan)

\begin{tabular}{|c|c|c|}
\hline Bulan & Pendapatan Jasa & $\begin{array}{c}\text { Kenaikan / } \\
\text { Penurunan }\end{array}$ \\
\hline Januari & 1.667 .945 & \\
\hline Februari & 1.539 .543 & $(128.402)$ \\
\hline Maret & 1.718 .225 & 178.682 \\
\hline April & 1.588 .405 & $(129.820)$ \\
\hline Mei & 1.905 .115 & 316.710 \\
\hline Juni & 1.077 .014 & $(828.101)$ \\
\hline Juli & 1.533 .304 & 456.290 \\
\hline Agustus & 1.638 .906 & 105.602. \\
\hline September & 1.539 .179 & $(99.726)$ \\
\hline Oktober & 1.592 .330 & 53.151 \\
\hline November & 1.617 .171 & 24.841 \\
\hline Desember & 1.631 .521 & 14.349 \\
\hline
\end{tabular}

Sumber Data : Transportasi BMT DARUSSALAM

Grafik Pendapatan Jasa

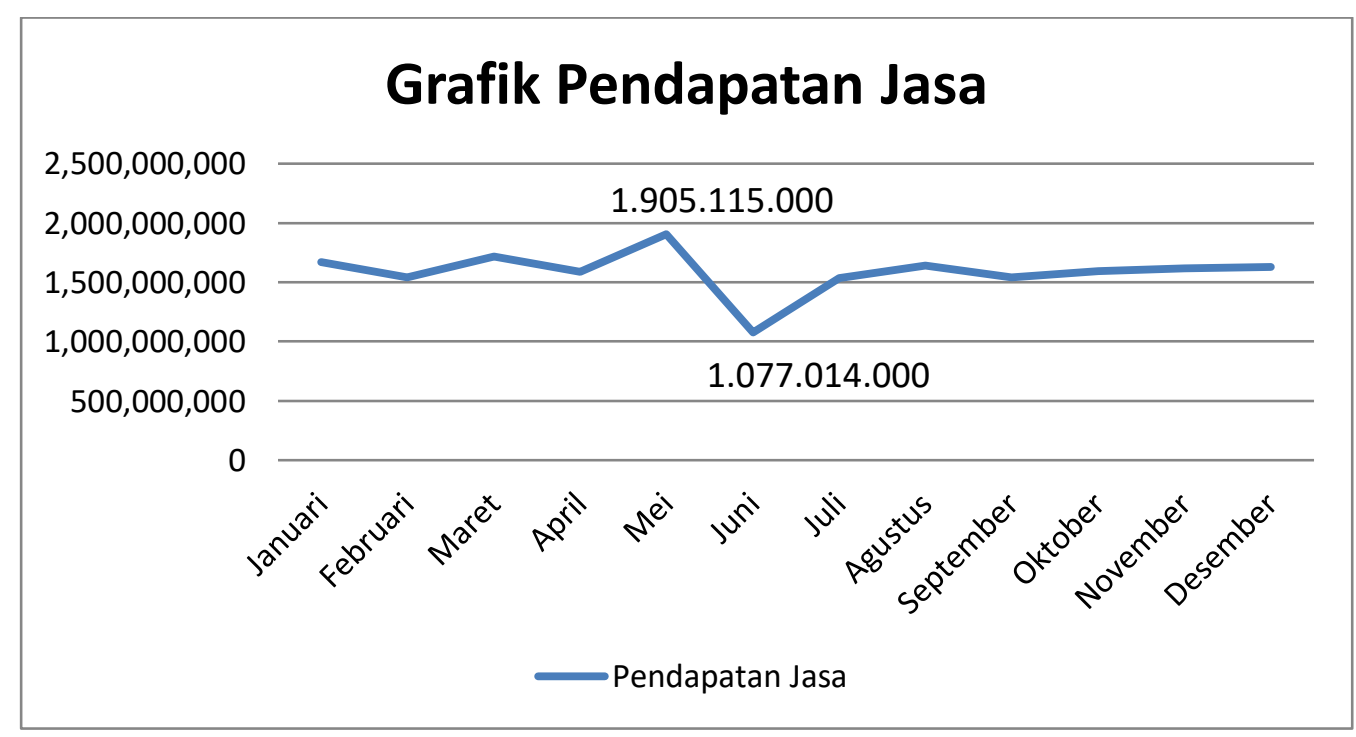

Berdasarkan tabel dan gambar di atas dapat dilihat bahwa pada periode 2019 Transportasi BMT DARUSSALAM pendapatan jasa yang meningkat terjadi pada bulan Mei dan mengalami penurunan di bulan Juni. Hal ini dianalisis dengan melihat laporan laba rugi perusahaan periode 2019, kemudian dari laporan laba rugi yang sudah dianalisis dibuat grafik pendapatan jasa untuk mengetahui peningkatan dan penurunan pendapatan jasa yang di didapatkan oleh perusahaan tersebut pada periode 2019 . 
Berdasarkan data dari perusahaan kemudian peneliti melakukan rekapitulasi beban usaha (biaya transport), dan peneliti menganalisis kenaikan atau penurunan beban usaha (biaya transport) pada setiap bulannya, maka hasilnya disajikan sebagai berikut :

\section{Analisis kenaikan atau penurunan beban usaha (biaya transport) BMT DARUSSALAM} periode 2019 (Dalam Ribuan)

\begin{tabular}{|c|c|c|}
\hline Bulan & Beban Usaha & $\begin{array}{c}\text { Kenaikan / } \\
\text { Penurunan }\end{array}$ \\
\hline Januari & 802.045 & $(72.286)$ \\
\hline Februari & 729.759 & 53.185 \\
\hline Maret & 782.944 & 23.522 \\
\hline April & 806.466 & 112.773 \\
\hline Mei & 919.239 & $(399.113)$ \\
\hline Juni & 520.126 & 237.527 \\
\hline Juli & 757.653 & 54.165 \\
\hline Agustus & 811.818 & $(26.912)$ \\
\hline September & 784.906 & 4.481 \\
\hline Oktober & 789.387 & $(24.312)$ \\
\hline November & 765.075 & 55.126 \\
\hline Desember & 820.201 & \\
\hline
\end{tabular}

Sumber Data : BMT DARUSSALAM

\section{Grafik Beban Usaha}

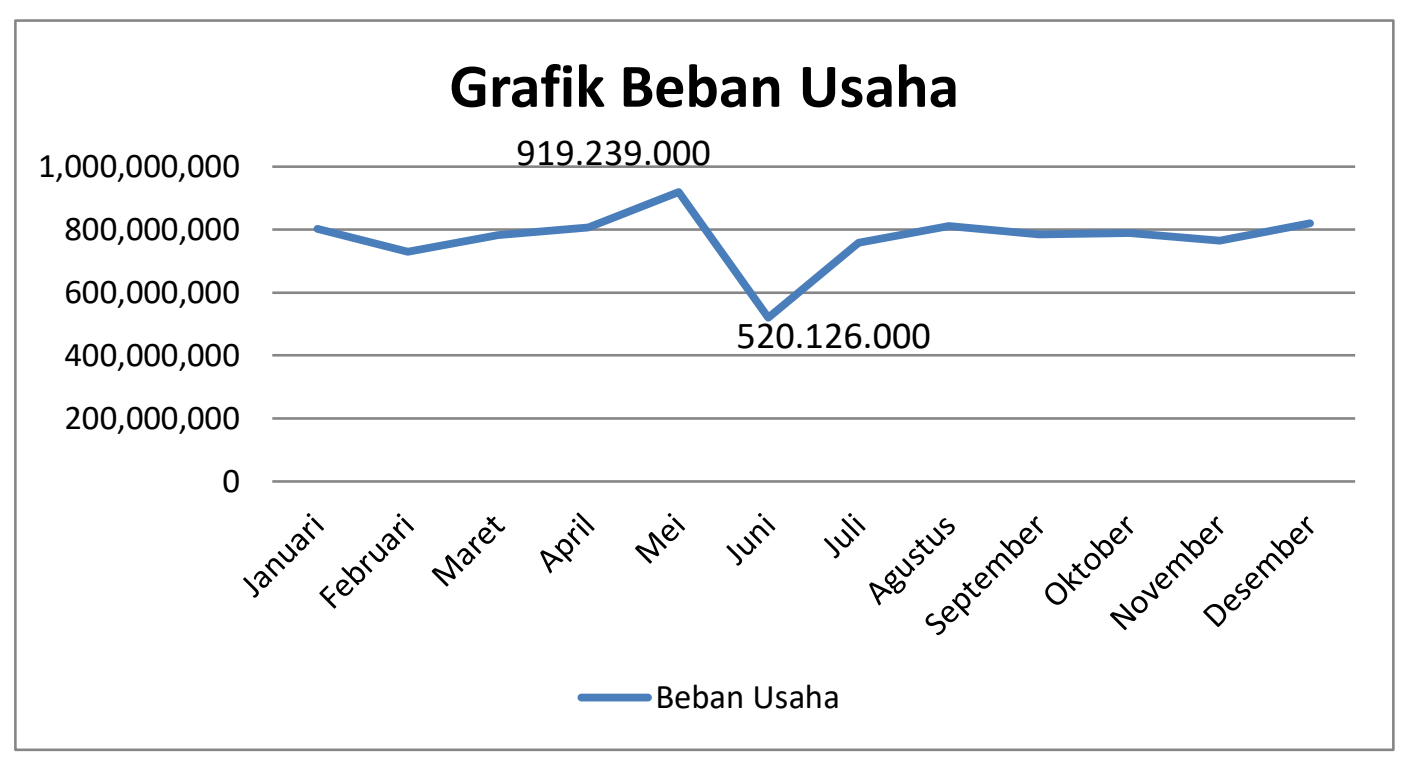

Berdasarkan tabel beban usaha dan Grafik Beban Usaha diatas dapat dilihat bahwa pada periode 2019 BMT DARUSSALAM sama seperti pendapatan jasa dengan beban usaha yang meningkat terjadi pada bulan Mei dan mengalami penurunan di bulan Juni. Hal ini dianalisis dengan melihat laporan 
laba rugi perusahaan periode 2019, kemudian dari laporan laba rugi yang sudah dianalisis dibuat grafik beban usaha untuk mengetahui peningkatan dan penurunan beban usaha yang dikeluarkan oleh perusahaan tersebut pada periode 2019.

Berdasarkan data dari perusahaan kemudian peneliti melakukan rekapitulasi laba usaha (laba kotor), dan peneliti menganalisis kenaikan atau penurunan laba usaha (laba kotor) pada setiap bulannya, maka hasilnya disajikan sebagai berikut :

\section{Analisis kenaikan atau penurunan laba usaha BMT DARUSSALAM periode 2019 (Dalam Ribuan)}

\begin{tabular}{|c|r|r|}
\hline Bulan & Laba Kotor & $\begin{array}{r}\text { Kenaikan / } \\
\text { Perununan }\end{array}$ \\
\hline Januari & 865.900 & \\
\hline Februari & 809.784 & 56.116 \\
\hline Maret & 935.281 & $(125.497)$ \\
\hline April & 781.939 & 153.342 \\
\hline Mei & 985.876 & $(203.937)$ \\
\hline Juni & 556.888 & 428.988 \\
\hline Juli & 775.651 & $(218.763)$ \\
\hline Agustus & 827.088 & $(51.437)$ \\
\hline September & 754.273 & 72.814 \\
\hline Oktober & 802.943 & $(48.669)$ \\
\hline November & 852.096 & $(49.153)$ \\
\hline Desember & 811.320 & 40.776 \\
\hline
\end{tabular}

Sumber Data : BMT DARUSSALAM

Grafik Laba Usaha

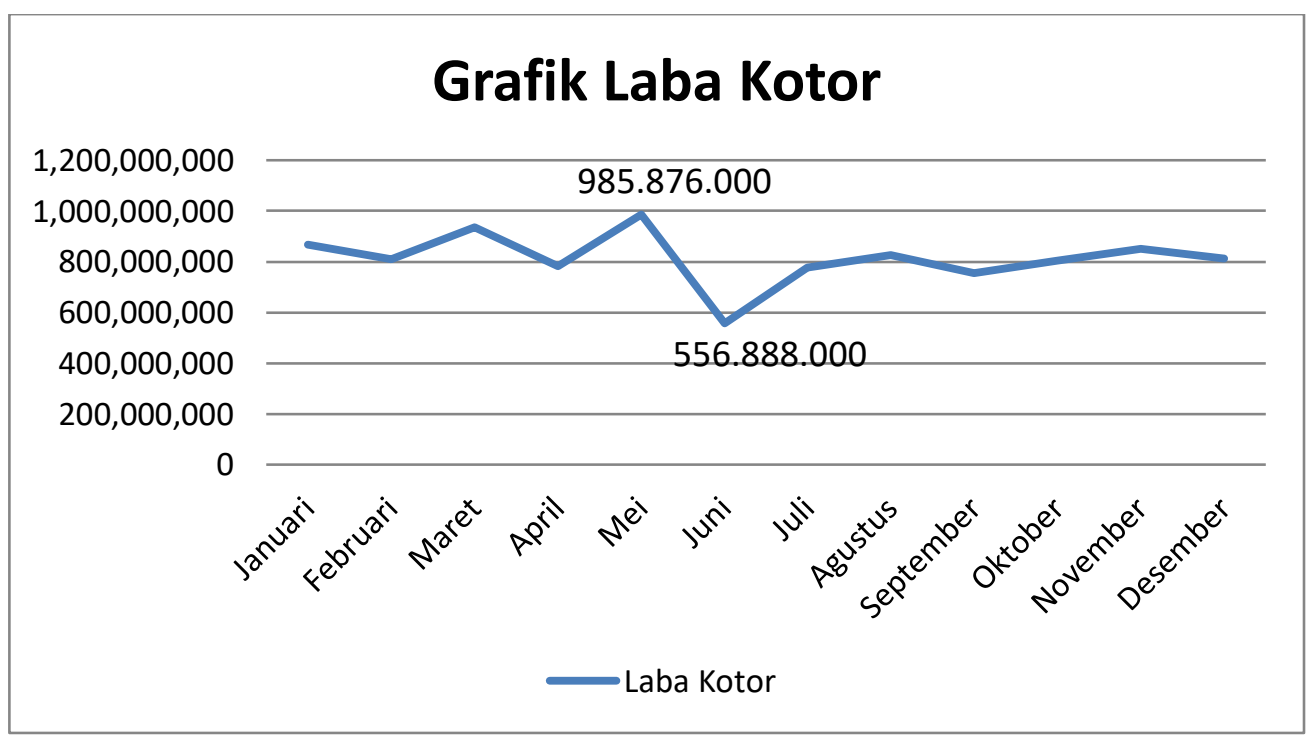


Berdasarkan tabel dan gambar laba usaha diatas dapat dilihat bahwa pada periode 2019 BMT DARUSSALAM sama seperti pendapatan jasa dan beban usaha pada laba usaha dalam hal ini adalah laba kotor yang meningkat terjadi pada bulan Mei dan mengalami penurunan di bulan Juni. Hal ini dianalisis dengan melihat laporan laba rugi perusahaan periode 2019, kemudian dari laporan laba rugi yang sudah dianalisis dibuat grafik laba usaha (laba kotor) untuk mengetahui peningkatan dan penurunan laba usaha (laba kotor) yang dihasilkan oleh perusahaan tersebut pada periode 2019.

Perhitungan analisis pendapatan jasa dan beban usaha terhadap laba usaha BMT DARUSSALAM periode 2019, sebagai berikut :

Pada Bulan Januari

$\begin{array}{ll}\text { Beban Usaha } & \mathrm{x} 100 \%=\frac{802.045 .000}{1.667 .945 .000} \times 100 \%=48 \% \\ \begin{array}{l}\text { Pendapatan Jasa } \\ \text { Laba Kotor }\end{array} & \mathrm{x} \mathrm{100 \%}=\frac{865.900 .000}{1.667 .945 .000} \times \frac{100 \%=52 \%}{100 \%}\end{array}$

\section{Analisis Jalur Pendapatan Jasa, Beban Usaha, dan Laba Usaha Bulan Januari}

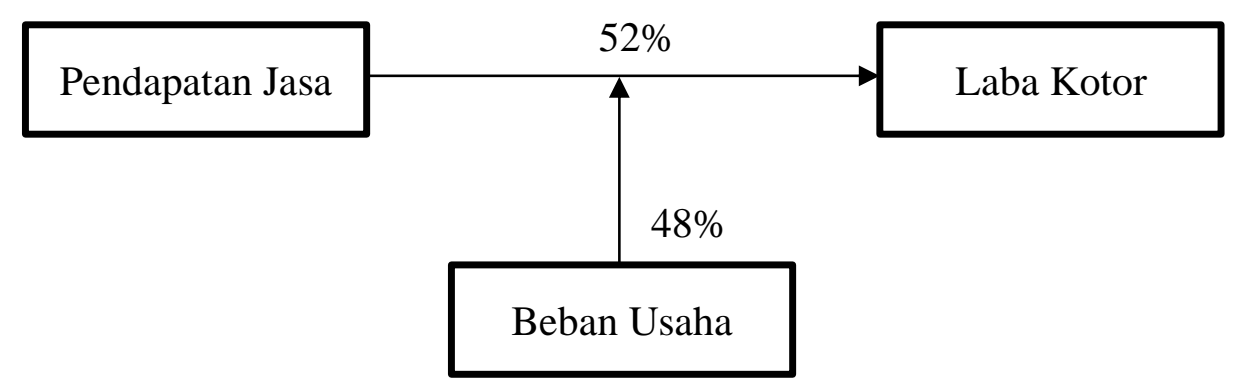

Pada Bulan Februari

$\begin{array}{lrl}\text { Beban Usaha } & \times 100 \%=\frac{729.759 .000}{1.539 .543 .000} \times 100 \%=47 \% \\ \text { Pendapatan Jasa } & \times 100 \%=\frac{809.784 .000}{1.539 .543 .000} \times \frac{100 \%=53 \%}{100 \%}\end{array}$

Analisis Jalur Pendapatan Jasa, Beban Usaha, dan Laba Usaha Bulan Februari

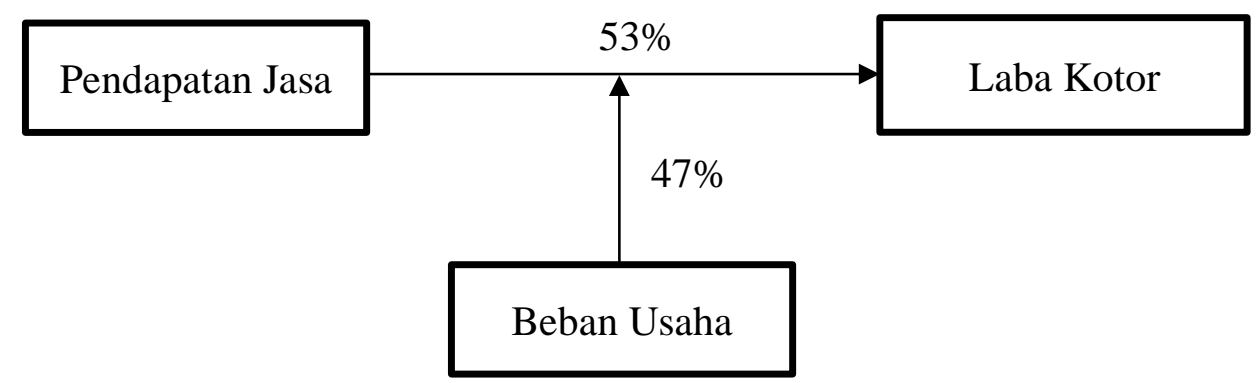

Pada Bulan Maret

Beban Usaha

Pendapatan Jasa

$$
x 100 \%=\frac{782.759 .000}{1.718 .225 .000} \times 100 \%=46 \%
$$




Laba Kotor $\quad \times 100 \%=\frac{935.281 .000}{1.718 .225 .000} \times \frac{100 \%=54 \%}{100 \%}$

Analisis Jalur Pendapatan Jasa, Beban Usaha, dan Laba Usaha Bulan Maret

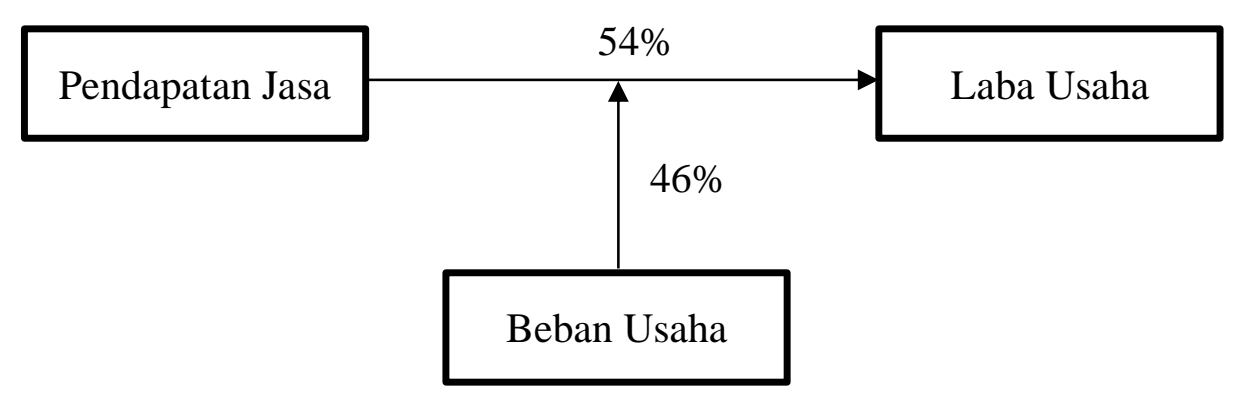

Pada Bulan April

\section{Beban Usaha}

Pendapatan Jasa

Laba Kotor

Pendapatan Jasa

$$
\mathrm{x} 100 \%=\frac{806.466 .000}{1.588 .405 .000} \times 100 \%=51 \%
$$

$$
\mathrm{x} 100 \%=\frac{781.939 .000}{1.588 .405 .000} \times \frac{100 \%=49 \%}{100 \%}
$$

Analisis Jalur Pendapatan Jasa, Beban Usaha, dan Laba Usaha Bulan April

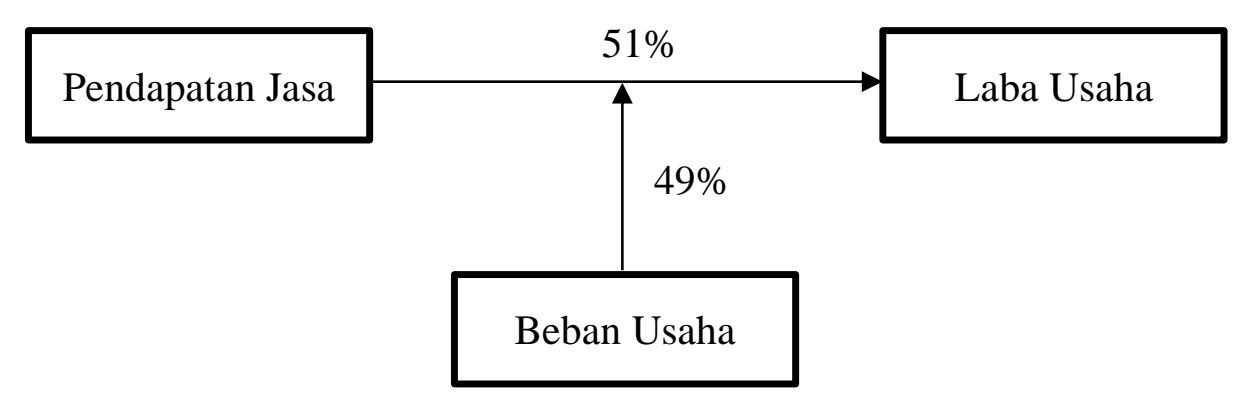

Pada Bulan Mei

Beban Usaha

Pendapatan Jasa

Laba Kotor

Pendapatan Jasa

$$
\begin{aligned}
\mathrm{x} 100 \% & =\frac{919.239 .000}{1.905 .115 .000} \times 100 \%=48 \% \\
\mathrm{x} 100 \% & =\frac{985.876 .000}{1.905 .115 .000} \times \frac{100 \%=52 \%}{100 \%}
\end{aligned}
$$

\section{Analisis Jalur Pendapatan Jasa, Beban Usaha, dan Laba Usaha Bulan Mei}

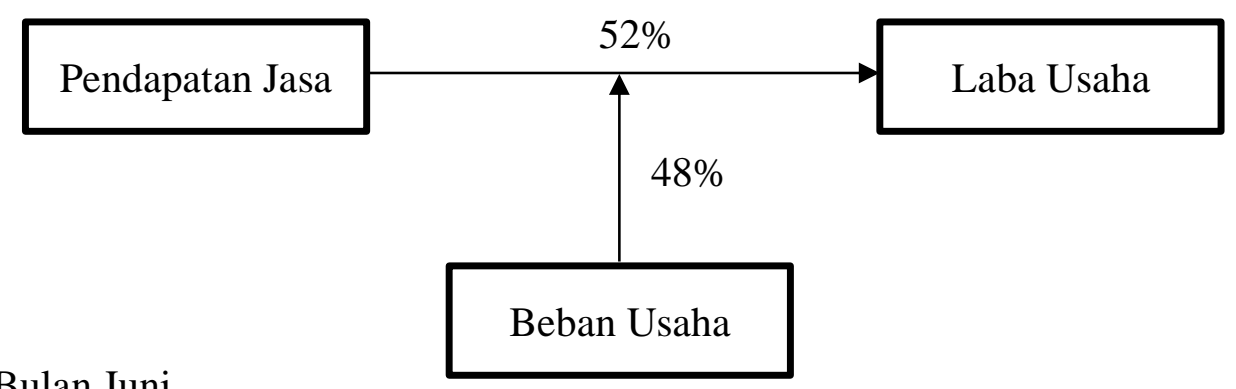

Pada Bulan Juni Beban Usaha

$$
\mathrm{x} 100 \%=\frac{520.126 .000}{1.077 .014 .000} \times 100 \%=48 \%
$$




$\begin{array}{lll}\text { Laba Kotor } & \times 100 \%=\frac{556.888 .000}{1.077 .014 .000} \times \frac{100 \%=52 \%}{100 \%}\end{array}$

Analisis Jalur Pendapatan Jasa, Beban Usaha, dan Laba Usaha Bulan Juni

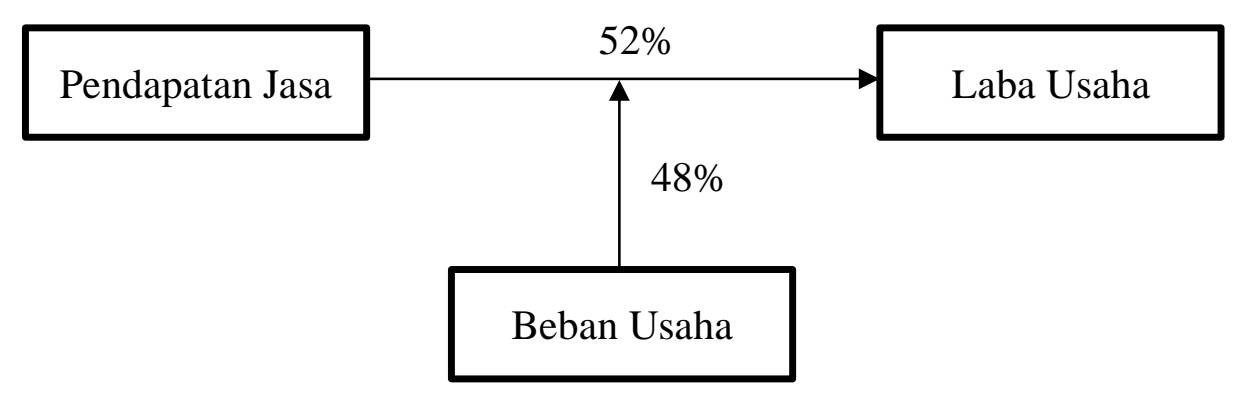

Pada Bulan Juli

Beban Usaha

Pendapatan Jasa

$\mathrm{x} 100 \%=\frac{757.653 .000}{1.533 .304 .000} \times 100 \%=49 \%$

$\frac{\text { Laba Kotor }}{\text { Pendapatan Jasa }}$

$\mathrm{x} 100 \%=\frac{775.651 .000}{1.533 .304 .000} \times \frac{100 \%=51 \%}{100 \%}$

Analisis Jalur Pendapatan Jasa, Beban Usaha, dan Laba Usaha Bulan Juli

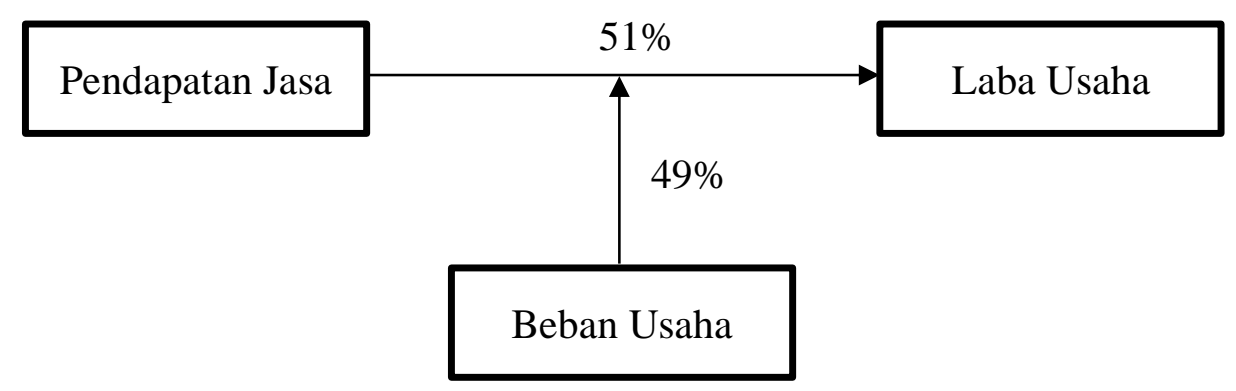

Pada Bulan Agustus

Beban Usaha

Pendapatan Jasa

Laba Kotor

Pendapatan Jasa $\mathrm{x} 100 \%=\frac{811.818 .000}{1.638 .906 .185} \times 100 \%=49 \%$

$$
\mathrm{x} 100 \%=\frac{827.088 .185}{1.638 .906 .185} \times \frac{100 \%=51 \%}{100 \%}
$$

Analisis Jalur Pendapatan Jasa, Beban Usaha, dan Laba Usaha Bulan Agustus

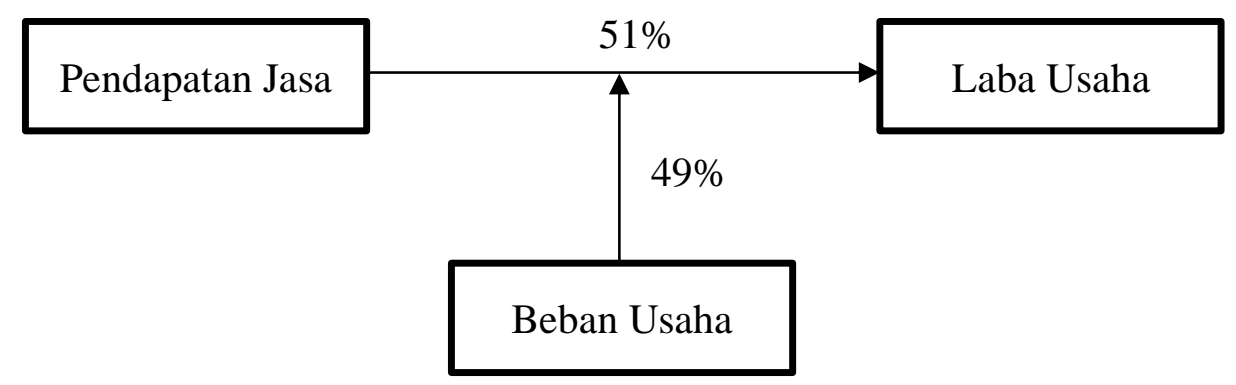

Pada Bulan September

Beban Usaha $\quad \mathrm{x} 100 \%=784.906 .000 \times 100 \%=51 \%$ 


$\begin{aligned} & \text { Pendapatan Jasa } \\ & \text { Laba Kotor }\end{aligned} \quad \mathrm{x} 100 \%=\frac{\begin{array}{l}1.539 .179 .693 \\ \text { Pendapatan Jasa }\end{array} \quad \frac{754.273 .693}{1.539 .179 .693} \times \frac{100 \%=49 \%}{100 \%}}{\frac{1}{10}}$

Analisis Jalur Pendapatan Jasa, Beban Usaha, dan Laba Usaha Bulan September

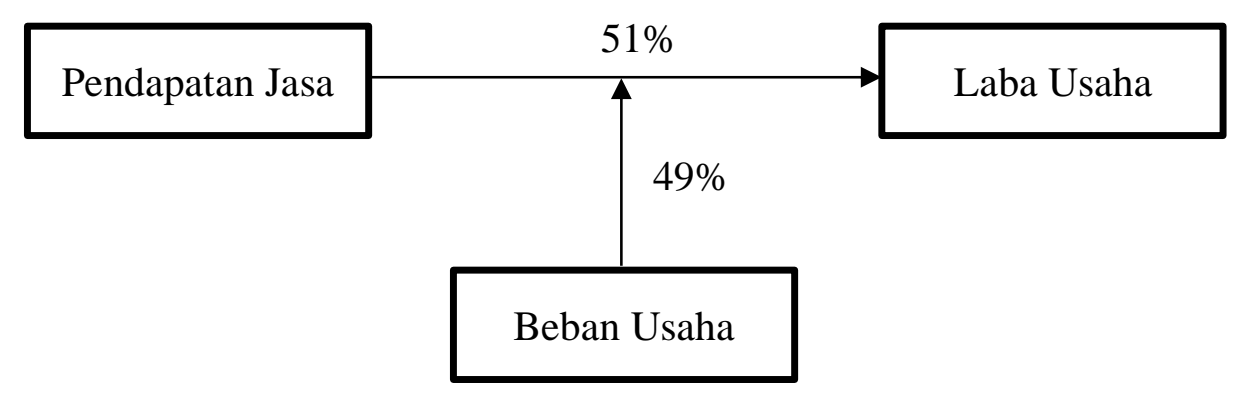

Pada Bulan Oktober

$\begin{array}{ll}\text { Beban Usaha } & \times 100 \%=\frac{789.387 .500}{1.592 .330 .828} \times 100 \%=50 \% \\ \text { Pendapatan Jasa } & \times 100 \%=\frac{802.943 .328}{1.592 .330 .828} \times \frac{100 \%=50 \%}{100 \%}\end{array}$

Analisis Jalur Pendapatan Jasa, Beban Usaha, dan Laba Usaha Bulan Oktober

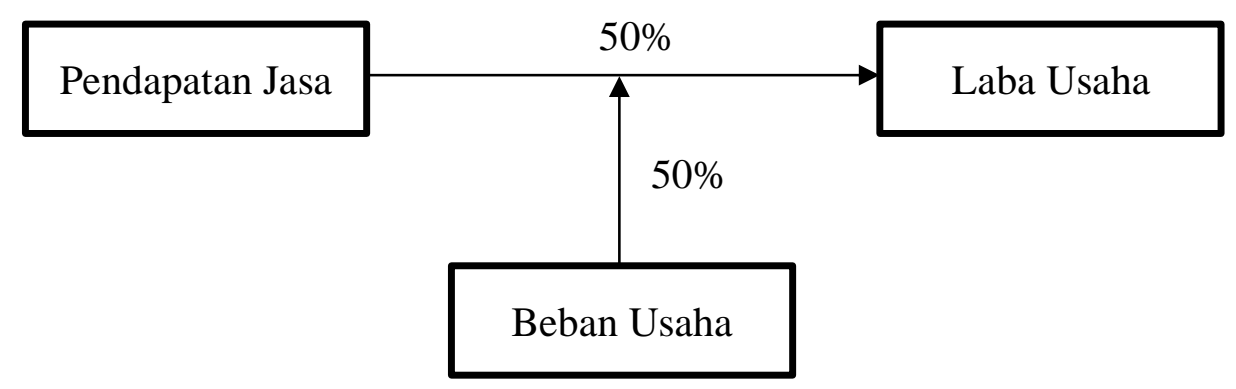

$\begin{aligned} & \text { Pada Bulan November } \\ & \text { Beban Usaha }\end{aligned} \quad \times 100 \%=\frac{765.075 .000}{1.617 .171 .967} \times 100 \%=47 \%$
$\begin{aligned} & \text { Pendapatan Jasa } \\ & \text { Laba Kotor }\end{aligned} \quad \times 100 \%=\frac{852.096 .967}{1.617 .171 .967} \times \frac{100 \%=53 \%}{100 \%}$

Analisis Jalur Pendapatan Jasa, Beban Usaha, dan Laba Usaha Bulan November

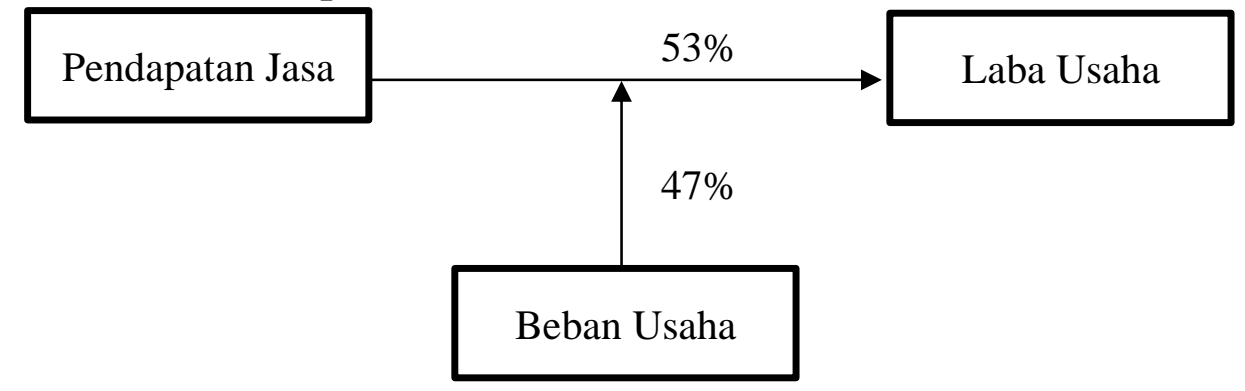




\begin{tabular}{|c|c|c|c|}
\hline \multicolumn{4}{|c|}{ Pada Bulan Desember } \\
\hline Beban Usaha & \multirow[t]{2}{*}{$\times 100 \%=$} & 820.201 .000 & \multirow[t]{2}{*}{$\mathrm{x} 100 \%=50 \%$} \\
\hline Pendapatan Jasa & & 1.631 .521 .228 & \\
\hline Laba Kotor & \multirow[t]{2}{*}{$\mathrm{x} 100 \%=$} & 811.320 .228 & $x 100 \%=50 \%$ \\
\hline Pendapatan Jasa & & 1.631.521.228 & $100 \%$ \\
\hline
\end{tabular}

\section{Analisis Jalur Pendapatan Jasa, Beban Usaha, dan Laba Usaha Bulan Desember}

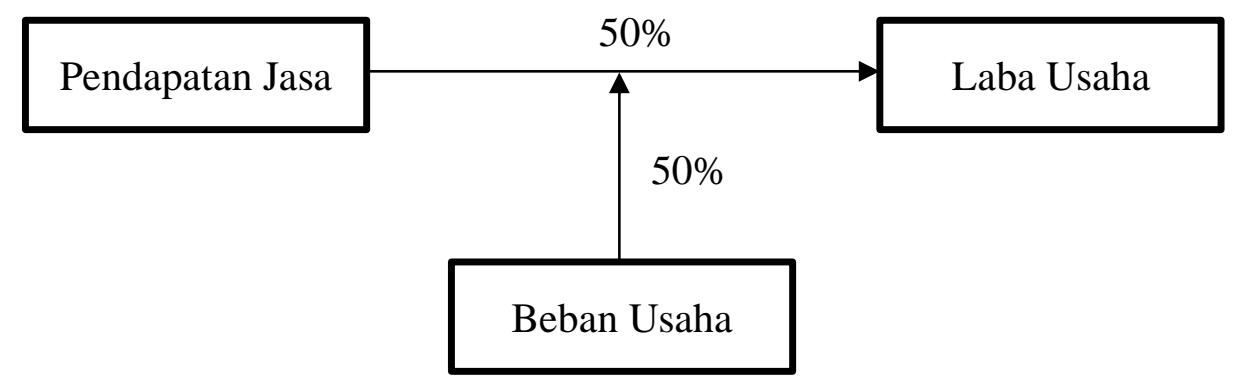

Hasil penelitian yang sudah peneliti uraikan di atas pada perusahaan BMT DARUSSALAM, pendapatan jasa, beban usaha, dan laba usaha selama periode 2019 sangat stabil hal ini ditujukan dengan grafik masing-masing yang stabil. Melihat ada 2 bulan yang tidak stabil tetapi jika rata-rata 2 bulan tesebut stabil

\section{KESIMPULAN DAN SARAN}

\section{Kesimpulan}

Berdasarkan hasil penelitian yang dilakukan oleh peneliti dan pembahasan mengenai analisis pendapatan jasa dan beban usaha terhadap laba usaha pada BMT DARUSSALAM, maka diambil kesimpulan sebagai berikut:

1. Pendapatan jasa yang di dapat oleh BMT DARUSSALAM sangat stabil pada periode 2019, hal ini dapat dilihat dari tabel dan grafik pendapatan jasa pada pembahasan, tidak terjadi kenaikan yang signifikan atau penurunan yang signifikan.

2. Beban usaha atau biaya transport yang dikeluarkan BMT DARUSSALAM sangat stabil pada periode 2019, hal ini di lihat dari tabel dan grafik beban usaha atau biaya transport pada pembahasan, tidak terjadi kenaikan yang signifikan atau penurunan yang signifikan.

3. Laba usaha atau laba kotor yang dihasilkan BMT DARUSSALAM sangat stabil pada periode 2019, hal ini di lihat dari tabel dan grafik laba usaha atau laba kotor pada pembahasan, tidak terjadi kenaikan yang signifikan atau penurunan yang signifikan. 


\section{Saran}

Atas penelitian yang peneliti lakukan ada beberapa saran yang akan peneliti kemukakan, adapun saran-saran yang peneliti kemukakan merupakan bahan pertimbangan untuk peneliti berikutnya, saran-saran tersebut yaitu:

1. Pertahankan kondisi yang sudah stabil untuk BMT DARUSSALAM, susah untuk menaikan pendapatan dan laba, kecuali perusahaan menambah jenis Angkutan lain.

2. Untuk peneliti selanjutnya meneliti 1 tahun atau lebih untuk mengetahui apakah terjadi variasi musim atau tidak pada BMT DARUSSALAM.

\section{DAFTAR PUSTAKA}

[1] fiska D. Jiasti, "Analisis Pengaruh Current Ratio, Quick Ratio, Receivable Turn Over, Dan Cash Turn Over Terhadap Laba Usaha (Koperasi Kopersemar Periode Tahun 2007-2009)," Skripsi Univ. Diponegoro, 2010.

[2] C. Liawan and V. N. Van Harling, "Analisis Perlakuan Akuntansi Pendapatan Jasa Konstruksi Pada Pt. Agrindo Makmur Abadi," Soscied, vol. 2, no. 1, pp. 44-51, 2019, doi: 10.32531/jsoscied.v2i1.169.

[3] R. Kartikasari, L. Suzan, and M. Muslih, "Perilaku Sticky Cost Terhadap Biaya Tenaga Kerja Dan Beban Usaha Pada Aktivitas Penjualan," J. Ekon. dan Bisnis, vol. 18, no. 2, pp. 65-80, 2015.

[4] B. I. Sappaile, “Konsep Penelitian Ex-Post Facto,” vol. 1, no. 2, 2010. 